УДК 342.5

DOI https://doi.org/10.51989/NUL.2021.4.15

\title{
ДО ПИТАННЯ ПРО ПРИНЦИПИ ПУБЛІЧНОЇ (ДЕРЖАВНОЇ) СЛУЖБИ
}

\author{
Селецький Олексій Вікторович, \\ кандидат юридичних наук, доцент, \\ декан юридичного факультету \\ Національного університету «Чернігівська політехніка»
}

\section{Шестак Лілія Володимирівна,}

кандидат юридичних наук, доцент, доцент кафедри трудового права, адміністративного права та процесу Національного університету «Чернігівська політехніка»

У статті піднімаються проблеми нормативного закріплення та юридичного змісту принципів публічної (державної) служби як базових керівних положень, на яких має ґрунтуватися державна служба. Автори підкреслюють, що наразі в наукових колах відсутнє єдине доктринальне бачення поняття «принцип», відповідно, немає єдиного підходу й до розуміння поняття та системи базових і допоміжних принципів здійснення публічної служби в Україні.

Дослідники аналізують зміст і сутність принципів публічної служби, визначених Законом України «Про державну службу», та зазначають, що кожен із них, маючи індивідуальний юридичний зміст та значення, тісно пов'язаний з іншими принципами. Законодавче закріплення переліку та юридичного змісту принципів публічної служби має сприяти їх чіткому розумінню і застосуванню як представниками державної (публічної) служби, так і особами, які користуються послугами публічних службовців. Виходячи з того, що проходження служби в окремих державних структурах може регулюватися спеціальними актами законодавства, автори відстоюють позицію про необхідність доповнення статті 4 Закону України «Про державну службу» частиною 2 такого змісту: «Принципи державної служби в окремих державних органах можуть бути визначені актами, що регулюють діяльність таких органів». Крім того, важливо з-поміж базових принципів публічної служби передбачити і такий, як принцип політичної та релігійної неупередженості, який викласти в такій редакції: «політичної та релігійної неупередженості - недопущення впливу політичних поглядів та релігійних переконань на дії та рішення державного службовця, а також утримання від демонстрації свого ставлення до політичних партій, блоків та їх об'єднань, релігійних організацій, демонстрації власних політичних поглядів та релігійних переконань під час виконання обов'язків по державній службі».

Натомість із числа принципів публічної служби, визначених Законом України «Про державну службу», має бути вилучений принцип рівного доступу до державної служби, як такий, що не відповідає положенням названого Закону України.

Ключові слова: публічна служба, принципи публічної служби, політична та релігійна неупередженість, доступ до публічної служби.

\section{Seletskyi Oleksii, Shestak Lillya. To the issue of the principles of public (civil) service}

The article deals with the issues of normative consolidation and legal content of the principles of public (civil) service as the basic guidelines on which the civil service should be based. The authors emphasize that nowadays there is no single doctrinal vision of the concept of "principle" in scientific circles, and, respectively, there is no single approach to understanding the concept and system of basic and additional principles of public service in Ukraine.

Researchers analyze the content and essence of the principles of public service, defined by the Law of Ukraine "On Civil Service" and note that each of them, having an individual legal meaning and significance, is closely related to other principles. Legislative consolidation of the list and legal content of the principles of public service should promote their clear understanding and application by representatives of the state (public) service as well as by people who use the services of public servants. Taking into account the fact that service in certain state structures may be regulated by special legislation, the authors justify their point of view regarding Article 4 
of the Law of Ukraine "On Civil Service" and state that it should be supplemented by part 2 of the following content: "The principles of civil service in certain public bodies can be determined by acts governing the activities of such bodies". In addition, it is important to include the principle of political and religious impartiality, which should be worded as follows: "political and religious impartiality - prevention of political views and religious beliefs refraining from demonstrating one's attitude to political parties, blocs and their associations, religious organizations, demonstrating one's own political views and religious beliefs while performing public service duties".

Instead, the principle of equal access to the civil service should be removed from the principle of the civil service, defined by the Law of Ukraine "On Civil Service", as it does not comply with the provisions of the mentioned Law of Ukraine.

Key words: public service, principles of public service, political and religious impartiality, access to public service.

Ефективність публічної (державної) служби прямо залежить від належного нормативно-правового регулювання ії діяльності, визначення змісту й обсягу її потреб та можливостей задля досягнення мети державного управління. Проте надмірна «зарегульованість» не $\epsilon$ ознакою покращення якості роботи публічних службовців, адже визначення чітких правових рамок діяльності публічних службовців може стати на заваді швидкому та ефективному впровадженню управлінських рішень тощо. Але віднайти баланс інтересів і можливостей держави, громадян та їхніх спільнот досить важко, так само й визначитися з межею доцільності правового регулювання діяльності окремих органів чи їхніх посадових осіб. Тому таке важливе значення мають принципи публічної (державної) служби - основні керівні засади їі здійснення, спрямовані на досягнення максимально корисних результатів за мінімальних затрат матеріальних, фізичних, психологічнихта інших ресурсів. Саме принципи державної служби дозволяють визначити напрями та цілі її діяльності, способи реалізації завдань і функцій публічної служби і загальну спрямованість на досягнення певного результату.

Питання дослідження принципів публічної (державної) служби не $\epsilon$ новими у вітчизняній правовій науці. Важливість, проблеми правового закріплення та юридичного значення й змісту окремих принципів публічної служби стали предметом наукових досліджень як знаних фахівців у сфері адміністративного права, так і молодих науковців. Зокрема, у своїх працях відповідні питання піднімали такі дослідники, як: В. Авер'янов, Ю. Битяк, В. Галай, В. Зуй, М. Карпа, Я. Качан, О. Лазор, Н. Янюк та інші. Проте їхні наукові доробки не вичерпують повноти змісту як окремих принципів публічної служби, так і їх системи, не забезпечують вирішення проблем їх нормативного закріплення та практичної реалізації. Bсе вищевикладене вказує на актуальність вибраної теми дослідження, особливо в умовах здійснення послідовної адміністративної реформи.

Метою статті $\epsilon$ дослідження проблем правового закріплення і практичної реалізації принципів публічної (державної) служби як основних керівних начал ії здійснення для практичної реалізації завдань та функцій держави.

Варто відзначити, що вітчизняне адміністративне законодавство не містить дефініції загального поняття «принцип публічної служби», а власне публічну службу ототожнюють із державною службою, виходячи з того, що це діяльність, спрямована на виконання завдань і функцій держави або представництво ії інтересів. Наразі в наукових колах відсутнє i єдине доктринальне бачення поняття «принцип», відповідно, попри важливість та юридичну значимість, немає єдиного підходу й до розуміння поняття і системи базових та допоміжних принципів здійснення публічної служби в Україні.

Як наукова категорія принципи публічної (державної) служби визначають вихідні положення і теоретичні ідеї, що відображають об'єктивні закономірності розвитку суспільства й держави, найбільш характерні риси організації та функціонування не тільки самої публічної служби, а й усієї системи державного апарату, судочинства та прокуратури, визначають зміст складних взаємовідносин усередині всього механізму держави [1, с. 29]. У даному випадку автор відзначає, що принципи публічної 
служби охоплюють не лише власне апарат держави, систему управлінських структур, але й службу в органах судової системи та прокуратури. Це вказує на єдність вимог, що висуваються як до працівників окремих державних органів, так і до організації діяльності всієї системи органів влади в цілому. Адже на основі принципів публічної служби організовується сам процес публічного управління, тобто продумана й обґрунтована впорядкованість дій щодо реалізації управлінських функцій, вибору форм, методів та прийомів управлінського впливу владних суб'єктів на підвладні. Проте навряд чи можна стверджувати, що принципи державної служби визначають зміст взаємовідносин між службовцями державного апарату. Адже такі відносини - це передусім правовідносини, які врегульовані нормами законодавчих та підзаконних актів, що визначають особливості, зміст і напрями діяльності окремих державних органів та їхніх посадових осіб, межі повноважень останніх тощо.

Варто також відзначити, що кожен із принципів публічної служби, маючи індивідуальний юридичний зміст та значення, власний «вектор» регулюючого впливу, все ж тісно пов'язаний з іншими принципами. На цю їхню особливість звертає увагу вітчизняна дослідниця I.I. Письменна, яка вказує, що принципи державної служби взаємодіють між собою в межах цілісної системи, врівноважуючи або посилюючи один одного, що дає змогу достатньою мірою розкрити їхню природу, індивідуальність і регулятивні можливості [2]. Тобто автор не лише відзначає єдність правової природи принципів публічної (державної) служби, але й вказує на їхній комплексний характер, цілісність та неподільність усієї системи принципів.

Доцільно зазначити, що перелік принципів державної служби закріплено Законом України «Про державну службу», ст. 4 якого називає та розкриває юридичний зміст таких керівних положень здійснення публічної служби: верховенства права, законності, професіоналізму, патріотизму, доброчесності, ефективності, забезпечення рівного доступу до державної служби, політичної неупередженості, прозорості та стабільності [3]. Власне, визна- чення змісту відповідних принципів на рівні законодавчого акта було здійснено вперше, що має сприяти їх чіткому розумінню і застосуванню як представниками державної (публічної) служби, так і особами, які користуються послугами публічних службовців. Ці принципи поширюють свою чинність на всіх державних службовців незалежно від займаної посади та виконуваної роботи. Причому, як відзначає Ю.П. Битяк, відповідних принципів публічні службовці мають дотримуватися як під час виконання обов'язків по державній службі, так і в позаслужбових відносинах, а також проявляти витримку, ввічливість, принциповість, уміння вислухати і зрозуміти позицію підлеглого чи громадянина в питанні, з якого він звернувся, та прийняти рішення відповідно до вимог чинних правових приписів [4, с. 21]. Таким чином, автор вказує на певну неповноту законодавчо закріплених принципів публічної служби (таке твердження $є$ безспірним), а також відзначає, що необхідність дотримання принципів публічної служби визначається наявністю в особи статусу державного службовця, а їх реалізація виявляється в безпосередніх, юридично значимих діях відповідної особи.

Звичайно, що перелікпринципів державної служби, визначений Законом України «Про державну службу», не $\epsilon$ вичерпним, оскільки діяльність окремих груп публічних службовців визначається спеціальними нормативними актами, в межах яких ураховується специфіка роботи відповідних служб чи органів, їхні взаємовідносини всередині державного органу та з іншими державними й недержавними структурами, громадянами тощо. Так, діяльність органів Національної поліції регулюється, крім загального Закону України «Про державну службу», ще й спеціальним нормативним документом - Законом України «Про Національну поліцію» [5], діяльність службовців Служби безпеки регулюється Законом України «Про Службу безпеки України» [6] тощо. Тому доречно ст. 4 Закону України «Про державну службу» доповнити частиною 2 в такій редакції: «Принципи державної служби в окремих державних органах можуть бути визначені актами, що регулюють діяльність таких органів». 
Таким чином, можна стверджувати, що принципи публічної служби можна поділити на дві групи: загальні принципи публічної служби, які поширюють свою чинність на всіх без винятку державних (публічних) службовців, а також принципи професійної діяльності публічних службовців окремих державних органів. Принципи кожної з груп доповнюють один одного, оскільки мають спільну спрямованість - упорядкування процедур з надання публічних послуг для реалізації завдань і функцій держави з метою задоволення прав та свобод громадян.

Варто також відзначити, що Законом України «Про державну службу» передбачені так звані базові, основні принципи здійснення публічної (державної) служби, перелік яких може бути доповнено в нормативних документах, що визначають порядок, умови та особливості публічної служби в окремих державних органах. Так, деякі принципи публічної служби знайшли своє відображення в Законах України «Про службу в органах місцевого самоврядування», «Про Національну поліцію» та інших актах. Але система принципів публічної служби не може бути сталою. Вона має враховувати зміни, що відбуваються в суспільстві, та вчасно й адекватно на них реагувати. Так, в умовах збройного конфлікту з Російською Федерацією та виникнення релігійних суперечок доречно було 6 у числі принципів визначити й такий, як принцип релігійної неупередженості, та передбачити його в п. 8 ч. 1 ст. 4 Закону України «Про державну службу», який викласти в такій редакції: «політичної та релігійної неупередженості - недопущення впливу політичних поглядів та релігійних переконань на дії та рішення державного службовця, а також утримання від демонстрації свого ставлення до політичних партій, блоків та їхніх об'єднань, релігійних організацій, демонстрації власних політичних поглядів та релігійних переконань під час виконання обов'язків по державній службі».

Попри те, що система загальних принципів державної служби визначена Законом України «Про державну службу», вважаємо за доцільне переглянути зміст принципу забезпечення рівного доступу до державної служби. Зміст цього прин- ципу розкривається у п. 7 ч. 1 ст. 4 Закону України «Про державну службу», відповідно до якого забезпечення рівного доступу до державної служби передбачає заборону всіх форм та проявів дискримінації, відсутність необґрунтованих обмежень або надання необґрунтованих переваг певним категоріям громадян під час вступу на державну службу та її проходження [3]. На наш погляд, таке тлумачення не відповідає сутності державної служби, ії̈ завданням і функціям. Адже під час вступу на державну службу та виконання обов'язків у статусі публічного службовця має бути враховано цілу низку факторів, які вказують на професійність та неупередженість публічного службовця: 1) рівень освіти та фахової підготовки особи; 2) досвід підвищення кваліфікації та саморозвитку ( участь у тренінгах, семінарах, курсах професійного зростання тощо, які допомагають «оновити» професійні знання, вміння та навички публічного службовця); 3) наявний досвід виконання повноважень з державної служби; 4) дотримання моральноетичних норм; 5) відсутність кримінальних конфліктів із законом та діянь, що можуть бути кваліфіковані як такі, що пов'язані з корупцією; 6) вільне володіння державною мовою тощо. На важливість фахової підготовки публічного службовця вказує вітчизняна дослідниця Л.Р. Біла-Тіунова, яка відзначає, що така вимога $\epsilon$ визначальною в разі вступу на публічну службу практично у всіх країнах ЄC [7, с. 239]. Власне, подане у п. 7 ст. 4 Закону України «Про державну службу» тлумачення принципу вільного доступу до державної служби частково суперечить принципу професіоналізму (п. 3 ст. 4), професійної компетентності (п. 5 ст. 2) та ст. ст. 19-20 названого Закону України, які визначають право на державну службу та встановлюють вимоги, яким має відповідати особа, яка претендує на заняття посади публічного службовця. Тобто можна говорити про вільний доступ до публічної служби як про відсутність дискримінації за ознаками раси чи статі щодо громадян України, які досягли повноліття та бажають зайняти посаду державного службовця. У зв'язку з вищевикладеним вважаємо за доцільне вилучити п. 7 ч. 1 ст. 4 Закону України «Про державну службу». 
Окремі дослідники відстоюють позицію про необхідність закріплення принципу соціального захисту державних службовців як одного з базових принципів державної служби [8, с. 243]. Але, на наш погляд, належний соціальний захист публічних службовців не повинен бути визначений власне як принцип державної служби. Це має бути передбачена законом система правових та організаційних заходів, які спрямовані на забезпечення соціального захисту публічних службовців і полягають y: збалансуванні законодавчо встановлених обмежень їхніх трудових прав додатковими заходами матеріального забезпечення; стимулюванні бажання таких осіб здійснювати важливу для держави трудову діяльність; компенсуванні втрачених засобів до існування в разі виникнення обставин, передбачених законодавством; забезпеченні стабільності кадрів у державній службі [8, с. 243]. Вважаємо, що правова захищеність публічних службовців також не повинна бути закріплена як окремий принцип, а має бути визначена як система законодавчо визначених дій, способів та можливостей, спрямованих на практичне забезпечення захисту прав і свобод публічного службовця як особи, на яку покладена реалізація окремих функцій держави, та як громадянина України.

Переконані, що перелік принципів публічної (державної) служби не повинен бути надто широким, оскільки в таких умовах принципи втрачають своє призначення, нівелюються і перетворюються на гасла, що не несуть реального юридичного та практичного змісту. Доречно чітко визначити завдання, межі повноважень та відповідальність публічних службовців, а також забезпечити практичну реалізацію принципу верховенства права як у діяльності публічної служби, так і щодо інших суб'єктів права.

У визначенні системи принципів публічної служби важливим $€$ їх відокремлення від обов'язків, стандартів, рекомендацій, правил, концептуальних положень щодо діяльності службовців, які теж можуть бути закріплені в окремих нормах законодавства, проте не $є$ тотожними принципам публічної служби [9, с. 154].

Таким чином, принципи державної служби - це основні керівні ідеї її здійснення, зумовлені природними правами людини та засновані на міжнародних стандартах публічної служби, що знайшли своє відображення в актах національного законодавства, які втілюють науково обґрунтовані основи реалізації завдань і функцій державної служби та сприяють ефективності політики держави в питаннях забезпечення прав і свобод громадян, побудови громадянського суспільства.

Підводячи підсумки дослідження, можна стверджувати про те, що принципи публічної (державної) служби є важливою складовою частиною законодавства, що визначає статус, завдання, повноваження та відповідальність державних службовців. Але це не означає, що їх перелік має бути невичерпним, оскільки в такому разі нівелюється їхнє засадниче призначення і зміст. Принципи публічної служби не повинні дублювати обов'язки, стандарти чи правила діяльності державних службовців.

Перелік принципів державної служби, що вміщений у ст. 4 Закону України «Про державну службу», має бути оновлений. На наш погляд, з нього має бути вилучений принцип рівного доступу до державної служби як такий, що не відповідає положенням названого Закону України. Натомість доречно доповнити систему принципів принципом релігійної неупередженості, а також доповнити статтю 4 частиною 2, в якій визначити, що принципи діяльності державних службовців окремих державних органів можуть бути передбачені актами законодавства, що регулюють їхню діяльність. Вважаємо, що система принципів публічної служби має мотивувати державних службовців до високопрофесійного виконання покладених на них обов'язків, а не лише визначати юридичні рамки діяльності та передбачати їхню відповідальність. 


\section{ЛITEPATУPA:}

1. Державна служба : підручник: у 2 т. / Нац. акад. держ. упр. при Президентові України, редкол. : Ю.В. Ковбасюк (голова) та ін. Київ, Одеса : НАДУ, 2012. Т. 1. 372 с.

2. Письменна I.I. Система принципів державної служби України в сучасних умовах суспільного розвитку. Вісник Академії митної служби України. Сер.: Державне управління. 2011. № 2. URL: http://nbuv.gov.ua/UJRN/vamcudu_2011_2_22

3. Про державну службу : Закон України від 10 грудня 2015 року. URL: https:// zakon.rada.gov.ua/laws/show/889-19\#Text (дата звернення: 04.07.2021).

4. Битяк Ю.П. Державна служба в Україні: організаційно-правові засади : монографія. Харків : Право, 2005. 304 с.

5. Про Національну поліцію : Закон України від 2 липня 2015 року. URL: https:// zakon.rada.gov.ua/laws/show/580-19\#Text (дата звернення: 04.07.2021).

6. Про Службу безпеки України : Закон України від 25 березня 1992 року. URL: https:// zakon.rada.gov.ua/laws/show/2229-12\#Tеxt (дата звернення: 04.07.2021).

7. Біла-Тіунова Л.Р. Службова кар'єра в Україні : монографія. Одеса : Фенікс, 2011. 540 с.

8. Калініченко 3.Д. Основні засади правового забезпечення соціального захисту державних службовців. Сучасні проблеми правового, економічного та соціального розвитку держави : тези доповідей VII Міжнародної науково-практичної конференції (м. Харків, 30 листопада 2018 р.). Харків, 2018. С. 242-244.

9. Янюк Н.В. Принципи публічної служби в національному законодавстві України: європейський вимір. Юридичний науковий електронний журнал. 2014. № 6. С. 153-157. 